\title{
Exploratory Study on Video Game Addiction of College Students in a Pandemic Scenario
}

\author{
José Gómez-Galán ${ }^{1,2} \odot$, Cristina Lázaro-Pérez ${ }^{3} \oplus$ and José Ángel Martínez-López ${ }^{4} \oplus$ \\ ${ }^{1}$ Department of Education, University of Extremadura, Spain \\ ${ }^{2}$ Cupey Campus, Ana G. Méndez University, Puerto Rico \\ ${ }^{3}$ Department of Political Sciences, Social Anthropology and Public Finances, University of Murcia, Spain \\ ${ }^{4}$ Department of Social Work and Social Services, University of Murcia, Spain
}

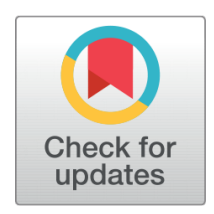

Received 2021-03-30
Revised 2021-04-19
Accepted 2021-05-31
Published 2021-07-15

Corresponding Author

José Ángel Martínez-López

Department of Social Work and

Social Services, University of

Murcia, Avda. Teniente Flomesta,

5, 30003 Murcia, Spain

DOI https://doi.org/10.7821/

naer.2021.7.750

Pages: $330-346$

Distributed under

Creative Commons CC BY 4.0

Copyright: (C) The Author(s)

\section{OPEN ACCESS}

\section{ABSTRACT}

The use of video games has increased significantly in the last decade. The young population has always been more inclined to use them. However, the risks of addiction to them are growing with the access to the Internet and new digital devices, the lower cost of them, and the lack of parental control. On the other hand, a weird circumstance as the COVID-19 pandemic involves weeks-long confinements, which may significantly influence increased consumption. This study aims to know university students' situation in Spain regarding the problem described in this pandemic scenario. It analyzes the use of video games and whether addiction risks appearance, examining which factors are determinants of this behavior. The method is based on various statistical techniques: descriptive analysis, the association between variables, and logistic regression to check the phenomenon studied, which are predictive variables. As a result, high video game consumption during confinement was got, finding addiction patterns in $16.6 \%$. The excessive use of social networks and being male show significant relevance. These results also show the existence of comorbidity, meaning that university students may suffer from psychological and psychiatric disorders linked to other consumptions. Health and academic authorities should consider this individual, social, and health problem and implement prevention, detection, and treatment programs.

\section{Keywords VIDEO GAMES, ADDICTION, DISORDER, UNIVERSITY STUDENTS, COVID-19}

\section{INTRODUCTION}

In the information and communication technology (ICT) society, the accessibility of digital devices and the possibilities they offer for leisure is increasing, especially among young people and adolescents. Video games, in particular, provide a wide variety of genres, and today, in many cases, they are free of charge, which contributes to the social generalization of their use. This easy entry to them, from the computer, mobile, or console (Connolly, Boyle, MacArthur, Hainey, \& Boyle, 2012), and the possibility of playing online, has 
allowed multiple forms of play: alone, with a rival, or massively (Chamarro et al., 2014). Today they make up a virtual world with thousands of players from different parts of the planet taking part simultaneously (Parra, Segura, Morales, \& López-Meneses, 2020), going from being a private or solitary leisure instrument to a shared activity that creates new social structures (Carrillo, 2015).

Today, access to video games differs significantly from previous decades. Although moderate use of video games can bring wide-ranging benefits (Mishra, Anguera, \& Gazzaley, 2016), their abuse can be a source of social problems and addictions (Carbonell, 2020; Carbonell, Chamarro, Oberst, Rodrigo, \& Prades, 2018).

The consumption of video games is developing and has some very determined characteristics: its easy accessibility, the possibility of doing it in an intimate space without supervision or social contact, the incorporation, its wide offer, incorporating associative or collaborative character, etc., makes it difficult to put limits to this type of addiction. Also, the lack of parental limits about its consumption is a handicap in the problem's awareness. Parents and educators require information regarding the diagnosis and treatment of this addiction.

The expansion of these online games has created a significant focus of interest by the primary social strata such as politics, parents, and the scientific community (Prot, McDonald, Anderson, \& Gentile, 2012), motivated mainly by the harmful consequences that excessive consumption can generate: social isolation, avoidance of daily routine activities (Kuss, Louws, \& Wiers, 2012), great inactivity by addicted people, etc. These behaviors can trigger obesity and chronic diseases (Beltrán, Devís, \& Peiró, 2012), aggressive behaviors (TorreLuque \& Aguayo, 2013), eating disorders (Cimino et al., 2018), depression (Strong, Lee, Chao, Lin, \& Tsai, 2018), low sensitivity to aggression (Carnagey, Anderson, \& Bushman, 2007), etc. In adolescents' case, some results confirm that video games' excessive use is associated with a series of problems that resemble a dependency syndrome (Tejeiro \& Bersabé, 2002).

Among the essential characteristics of online video game addiction, DSM-5 includes repeated and persistent behavior over many hours that produce clinically relevant impairment, over 12 months, and is accompanied by psychological, social, tolerance, and withdrawal symptoms (American Psychiatric Association, 2013). The ICD-11, to determine video game use disorder, considers a model of behavior with persistent or recurrent gaming, both online and offline, and requires 12 months for its diagnosis (King \& Potenza, 2019). These two diagnostic manuals will allow us to differentiate between disorder and social concern and between people who use video games for entertainment and those who use them in a professional context (Carbonell, 2020).

However, in the medical field, video game addiction is still a topic of debate among researchers and health professionals (Aarseth et al., 2017; Buiza-Aguado et al., 2017; Friedman, 2020; Király \& Demetrovics, 2017; Király et al., 2020). It should be noted that, according to the DSM-5 (American Psychiatric Association, 2013), there is insufficient and inadequate evidence to determine that Internet gaming disorder is a unique disorder, nor clear criteria to classify it. 
Moreover, it is difficult to pinpoint the difference between what could be understood as an addiction or an Internet gaming disorder (Andreassen et al., 2016) (Andreassen et al., 2016). Diagnostic criteria such as those referred to above can be assumed, but it is very complex to determine to what extent this can be precisely established. On the other hand, it is also difficult to distinguish between what would be Internet addiction disorder (IAD) and internet gaming disorder (IGD), whose impact has been determined at early ages (Fam, 2018; Paulus, Ohmann, von Gontard, \& Popow, 2018), and the presence of video games in this context. It is complex to separate the use made of the network -which can be used, for example, to play games- and its implications in the psychological sphere. However, today it seems logical to think that addiction does not have to involve consuming toxic substances (as may be the case, for example, gambling) for it to be accepted by the medical and psychiatric community. There would be no theoretical reason why other problematic and habitual behaviors (such as shopping, work, exercise, video games themselves, etc.) could not be classified as a genuine addiction (Griffiths \& Pontes, 2014). However, and in an educational context, it would not be so important to analyze it exclusively with the health or clinical field frameworks. It is more interesting to establish its possible impact on training processes, as is the case of university studies, although all these perspectives should naturally be considered as a whole

A relevant and indispensable question is determining the damage that video games can cause in the respective contexts in which the young person develops: academic, family, and personal (Kuss \& Griffiths, 2012; Van-Rooij, Schoenmakers, Vermulst, Den Eijnden, \& De Mheen, 2011). In this way, any initiative to prevent maladaptive behavior related to video game addiction could be addressed more effectively. Thus, any initiatives to prevent maladaptive behaviors related to video game addiction could be managed more effectively. Especially when the cause may be due to a lack of social integration and supports, which can lead to increased isolation and increased video game consumption that, in turn, fuels a lack of social contact (Paulus et al., 2018; Phan, Prieur, Bonnaire, \& Obradovic, 2020).

As with the socialization of other addictions such as alcohol and tobacco, video games are implemented in today's society in young people. Their consequences often go unnoticed both by health institutions and, in this case, by university institutions. Although integration of the digital paradigm in higher education is necessary (Cabrero \& Óscar Costa Román, 2018; González-Zamar, Abad-Segura, López-Meneses, \& Gómez-Galán, 2020; Roig-Vila \& Moreno-Isac, 2020), strategies that go beyond didactic aspects are not frequent, when today ICTs should be considered as an object of study and not only as instructional resources (Rosa, Bucheli, Galán, \& Meneses, 2019). Here, training programs to prevent addictions generated within these powerful technologies and media should be developed.

Due to the first wave of the COVID-19 pandemic, in March 2020, a state of alarm was declared in Spain and subsequent confinement for several months. During this stage, the use of the Internet and digital devices, as a pastime and socialization, increased due to the social distancing and mobility limitation measures imposed (Ariza, Monzonís, Magaña, \& Méndez, 2021; Balluerka et al., 2020; Gómez-Galán, Ángel Martínez-López, Lázaro-Pérez, 
\& Sánchez-Serrano, 2020). Some studies have indirectly determined that Spain registered global web traffic peaks (Orte \& Nevot-Caldentey, 2020).

The university population increased its consumption of social networks and video games (Gómez-Galán, Ángel Martínez-López, Lázaro-Pérez, \& García-Cabrero, 2021). The pandemic, therefore, may have contributed to the increase in the factors risk in video game addiction among students (Pasquale, Chiappedi, Sciacca, Martinelli, \& Hichy, 2021). This makes it essential to determine and describe this situation to get information from those months and subsequent comparative studies.

\section{MATERIAL AND METHODS}

\subsection{Objectives}

Video game addictions are present in scientific studies from different disciplines: psychology, psychiatry, sociology, education, etc. In all of them, it is clear how this type of addiction has consequences in the subjects' presence and repercussions shortly. This research aims to address this social phenomenon by pursuing the main objective (PO): to discover addiction to video games by Spanish university students during the first wave of the COVID-19 pandemic.

Apart from this general objective, two secondary objectives are pursued because of the fieldwork's characteristics. In the first place (SO1), the aim is to determine whether this type of addiction is related to socio-demographic factors or addictions to other toxic substances or social networks to establish a pattern of students addicted to video games. Secondly (SO2), check whether it is a problem of incidence in the university world so that, if so, the university authorities should create prevention and assistance programs. The research hypothesis is that video game addiction in university students is determined by other addictions (too toxic substances and/or the Internet/social networks), so comorbidity and sociodemographic variables are not defined.

Of course, this work's objectives are focused on the field of educational sciences to describe a situation that can affect students in their higher education studies. To guarantee a formative quality framework, the university authorities should take into account to adopt preventive measures. Therefore, it is not research in psychology, which seeks to establish degrees of addiction or clinical nature standards. This work aims to determine addiction in the use of video games by university students to prevent this problem within the framework of healthy spaces in higher education. The COVID-19 pandemic may have intensified this.

\subsection{Study Design and Sample}

The study was carried out in a cross-sectional manner between June 1 and 15 through a simple random sample of university students from different Spanish universities. Therefore, it has been implemented during the period of confinement in Spain because of the first wave of the COVID-19 pandemic, thus reflecting the situation described during all the weeks that it lasted. 
To carry out this cross-sectional, descriptive, and exploratory research, the Declaration of Helsinki's guidelines and the ethical protocols of the universities of the authors of the study were followed. Although in Spain, approval is only required for experimental studies and not for descriptive studies, as in this case, the authors subscribed to and signed the Codes of Good Practice for Research on Human Subjects required by the universities. The study was registered by the research team composed of the authors under code No. REPRIN-PEM-04B.

Following the Declaration of Helsinki, the participants in this research $(\mathrm{N}=310)$ gave their consent before applying the questionnaire, which was treated confidentially and anonymously at all times. It was carried out through a computerized and telematic application managed by the University of Murcia and designed to maintain confidentiality at all times. Once the instrument was accessed (which could be done through any device), the respondent had to give prior consent and accept the ethical conditions explained on the presentation screen.

The sample was applied to groups of students from 14 different Spanish universities through professors who collaborate directly or indirectly with the research team that carried out the work. At all times, they were informed in detail of the entire process to be followed. As we have pointed out, permission was always got before applying the questionnaire by the participants, both for those who offered the link and those who responded to the items presented.

\subsection{Variables Used}

In the research's development, the Game Addiction Scale for Adolescents (GASA, short version) created by Lemmens, Valkenburg, and Peter (2009) and validated in Spain by Irles, Gomis, Campos, and González (2018). This scale considers seven criteria that correspond to each of its seven items: salience, tolerance, emotion, abstinence, relapse, conflict, and problems. Each answer is scored on a 5 -point Likert scale ( $1=$ never, $2=$ rarely, $3=$ sometimes, $4=$ often, and $5=$ very often).

The dependent variable in this research is video game addiction. When the criteria used have a value higher than 3 ("sometimes"), the game is defined as problematic. To determine video game addiction, an application is used in which subjects who meet at least half of the criteria are included.

The independent variables used are grouped into two categories: socio-demographic and addictions to toxic substances or social networks. Regarding the socio-demographic variables, the following have been selected: 1) Gender (male/female), 2) Age ( $<21$ years, 21-24 years, 25-63 years, and >64 years), and 3) branch of knowledge of the degree (Sciences, Health Sciences, Social; Art and Humanities; and Legal Sciences and Engineering and Architecture).

Logically, in the research carried out, the variables related to drug use were of great interest in the search for comorbidity. For this reason, the World Health Organization (WHO) ASSIST questionnaire was used to determine drug use risk. It comprises eight questions that seek to assess addiction's risk to different substances: alcohol, tobacco, hallucino- 
gens, amphetamine-type stimulants, sedatives, inhalants, sleeping pills, cannabis, opiates, cocaine, and other drugs (WHO ASSIST Working Group, 2002). Although the ASSIST test was initially designed to be administered by primary care health professionals, we considered it very useful in our research setting. Due to its characteristics (number of items, response scale, psychometric properties, criteria for evaluating the presence of addiction, etc.), it was ideal for its application and for obtaining the information sought.

It was also valuable to know the risk of addiction to social networks. As with video games, young people today extensively use digital technologies and media, which could also be related to each other. For this purpose, the Social Network Addiction Scale (ARS) by Escurra and Salas (2014), focused precisely on young university students, was used. It is a validated and reliable 24-item instrument with a Cronbach's Alpha above 0.80, which shows a high internal consistency established by García-Bellido, González Such, and Jornet (2010).

ARS scale is divided into three subscales, each focusing on different factors. The first, Obsession with Social Networks (Factor I, Cronbach's Alpha: 0.91), examines the anxiety, discomfort, or worry caused by not using social networks, and in parallel, the recurrent thinking with them. The second, Lack of Personal Control in the Using of Social Networks (Factor II, Cronbach's Alpha: 0.88), focuses precisely on the lack of control concerning social networks and how this affects habitual tasks and studies. The third, Excessive Use of Social Networks (Factor III, Cronbach's Alpha: 0.92), is related to the inability to control the use of social networks, with excessive use of them.

\subsection{Statistical Analysis}

The exploitation of results was structured in 3 steps through the SPSS v.24 programs. First, a descriptive analysis of the profile of the young university students was carried out. Second, a cross-table analysis was carried out using the dependent variable: addiction to video games by university students according to their level of significance of the chi-square test $(\mathrm{p}<0.005)$. Third, binary logistic regression was performed to predict the variables that determine that addiction to video games. With this test's application, age was established as a continuous variable (rather than a discrete variable) in cross tables and frequency analysis. The forward model was the method used in binary logistic regression. The coefficients are re-evaluated and their significance automatically, and all non-statistically significant variables are eliminated (Berlanga \& Vilà, 2014).

\section{RESULTS}

In a first descriptive approach to the results, $69.9 \%$ are women and $30.1 \%$ men. The average age is 23.7 years old. The most significant number, making an age distribution, is between 21 and 24 years of age (46.1\%); in second place are those under 21 years old (31.3\%); third place is university students over 24 years old (22.6\%). There was an overrepresentation of Social and Legal Sciences, which accounted for $47.5 \%$ of university students regarding the branch of knowledge. 
Of the total number of participants, $16.6 \%$ show an addiction to video games. Of these, $46.7 \%$ were women, and $53.3 \%$ were men; therefore, we observed that the difference according to gender was tiny. As regards addictions to toxic substances, there were 4 that presented a percentage $\geq 10 \%$ : alcohol (36.2\%), tobacco (33.2\%), cannabis (22.9\%), and sedatives without a doctor's prescription (10.3\%). About addiction to social networks, according to factors, $9.0 \%$ showed dependence to Factor 1 (Obsession with social networks), $27.7 \%$ to Factor 2 (Lack of personal control in using social networks), and $47.1 \%$ to Factor 3 (Excessive use of social networks).

Once the descriptive analysis was obtained, a cross-table analysis was performed, establishing video game addiction as a dependent variable. We show below (Table 1) the obtained results with Pearson Square Chi (significance level $\mathrm{p}<0.05$ ).

\begin{tabular}{|c|c|}
\hline 1. Gender & 9. Addiction Inhalants \\
\hline Ref. Woman & Ref. No \\
\hline (1) Man & (1) Yes \\
\hline 2. Age (Continue) & 10. Addiction Sedatives \\
\hline Ref. $\leq 20$ & Ref. No \\
\hline (1) $21-24$ & (1) Yes \\
\hline$(2) \geq 25$ & 11. Addiction Hallucinogens \\
\hline 3. Knowledge Branch & Ref. No \\
\hline Ref. Arts \& Humanities & (1) Yes \\
\hline (1) Science & 12. Fam. Addiction Opiates \\
\hline (2) Engineering \& Architecture & Ref. No \\
\hline (3) Health Sciences & (1) Yes \\
\hline (4) Social \& Legal Sciences & 13. Fam. Addiction Other Drugs \\
\hline 4. Addiction Tobacco & Ref. No \\
\hline Ref. No & (1) Yes \\
\hline (1) Yes & 14. Addiction Networks Factor 1 \\
\hline 5. Addiction Alcohol & Ref. No \\
\hline Ref. No & (1) Yes \\
\hline (1) Yes & 15. Addiction Networks Factor 2 \\
\hline 6. Addiction Cannabis & Ref. No \\
\hline Ref. No & (1) Yes \\
\hline (1) Yes & 16. Addiction Networks Factor 3 \\
\hline 7. Addiction Cocaine & Ref. No \\
\hline Ref. No & (1) Yes \\
\hline \multicolumn{2}{|l|}{ (1) Yes } \\
\hline \multicolumn{2}{|l|}{ 8. Addiction Stimulants } \\
\hline \multicolumn{2}{|l|}{ Ref. No } \\
\hline (1) Yes & \\
\hline
\end{tabular}

According to the results of the crossed tables, an association with gender $(\mathrm{p}=0.000)$, addiction to social network Factor $1(\mathrm{p}=0.000)$, addiction to social network Factor 2 $(\mathrm{p}=0.006)$, and addiction to social network Factor $3(\mathrm{p}=0.003)$ are observed. Therefore, we can keep the relationship between gender and habits to social networks in general 
(regardless of the factors) with video game addiction.

Subsequently, a binary logistic regression was performed through the adelante method to determine if socio-demographic variables related to addiction to toxic substances or social networks can predict university students' dependence on video games. Table I show the variables used.

The binary logistic regression model was statistically significant $X^{2}=31.168, p<0.0005$ with video game addiction in the university students studied. The model explained $17.4 \%$ (Nagelkerke's $\mathrm{R}^{2}$ ) of video game addiction variance and correctly classified $86.1 \%$ of the cases. Moreover, according to the Hosmer-Lemeshow test, there were no significant differences between the results observed and those predicted ( $\mathrm{p}=0.951)$.

The binary logistic regression showed three predictive variables of the phenomenon of video game addiction: gender, addiction to social networks in Factor 1 and Factor 3. First, regarding the gender variable, it presents an $\mathrm{OR}=3.161$ IC95\%[1.594-6.269], $p=0.001$. In relation to the addiction of Factor 1 of social networks, it shows an $\mathrm{OR}=4.079$ IC $95 \%[1.570-10.600], p=0.004$. In third place, the addiction to Factor 3 of social networks expresses an $\mathrm{OR}=2.142$ IC95\%[1.016-4.517], $p=0.045$.

Thus, concerning the socio-demographic variables, being male predicts the addiction to video games, having three times more possibilities of falling into this addiction than a woman. Addiction to social networks is closely connected to video game addiction, especially about Factors 1 (Obsession with social networks) and 3 (Excessive use of social networks) of the subscale of addiction to social networks, with a university student with these addictions being 3 and 2 times more likely, respectively, to have an addiction to video games than one without this type of addiction (Table 2).

\begin{tabular}{|c|c|c|c|c|c|}
\hline & \multirow[t]{2}{*}{ B } & \multirow[t]{2}{*}{ Sig. } & \multirow[t]{2}{*}{$\operatorname{Exp}(B)$} & \multicolumn{2}{|c|}{ 95\% C.I. $\operatorname{Exp}(B)$} \\
\hline & & & & Lower & Superior \\
\hline Gender (1) & 1,151 & 001 & 3,161 & 1,594 & 6,269 \\
\hline Addiction Factor 1 (1) & 1,406 & ,004 & 4,079 & 1,570 & 10,600 \\
\hline Addiction Factor 3 (1) & 0,762 & 0,045 & 2,142 & 1,016 & 4,517 \\
\hline Constant & $-2,780$ & 0,000 & 0,062 & & \\
\hline
\end{tabular}

\section{DISCUSSION}

The socialization of video games is a reality established in the young population they live in every day. Numerous research studies conducted on college students have shown how video games' abuse can lead to mental disorders (Cangas et al., 2019; Hsieh, Hsiao, Yang, Liu, \& Yen, 2018; King, Delfabbro, Zwaans, \& Kaptsis, 2013; Ni, Yan, Chen, \& Liu, 2009) and impact daily tasks.

In a situation as unique as the one suffered by the COVID-19 pandemic, which involved confinement and continued stay at home, abuse in the consumption of video games could 
occur. In the present investigation, we observe how the addition to them is currently in $16.6 \%$ of Spanish university students. Although it may seem a compact figure initially, it must be considered that this type of addiction affects both personally and socially, affecting social habits and work and professional obligations. Therefore, this figure must be taken with due consideration since this group of students can develop psychological and psychiatric pathologies, besides presenting problems in following the students' academic development.

Although it is difficult to compare data from some research developed in a pre-pandemic context, it can be determined that it is a significant percentage. Concerning the objectives pursued, it has been seen that in practically all educational stages when excessive use of video games is carried out, academic performance suffers to a greater or lesser extent (Becerra, 2011; Irles, Perona, \& Baños, 2015; Llorca, Bueno, Villar-Fernández, \& Diez, 2010), which is not an exception in higher education (Cuberos et al., 2017). Although moderate video game use can be positive (Coknaz et al., 2019), even in a pandemic scenario (Marston \& Kowert, 2020), this is not the case when consumption is excessive.

Binary logistic regression has shown that video game addiction is determined by gender and social network addiction, specifically, Factor 1 and Factor 3 of the social network addiction scale.

About gender, men are more likely to be addicted to video games than women. This data is in line with other research (Brunborg, Mentzoni, \& Frøyland, 2014; Buono et al., 2020; Goudriaan, Oosterlaan, de Beurs, \& den Brink, 2004; Hsieh et al., 2018; Phan et al., 2020; Ross, Månsson, \& Daneback, 2012) showing an over-representation of men concerning video game addiction.

With social networks, it can be seen that video game addiction is related to addiction to Factors 1 and 3, i.e., the obsession with social networks and excessive use of them (Mentzoni et al., 2011; Quaglieri et al., 2020). In this sense, we observe comorbidity of addiction associated with the possibilities generated by new technologies in young people: video games and social networks, in the same way that previous studies found the co-occurrence of several addictive behaviors (Kuss \& Griffiths, 2012; Wang, Ho, Chan, \& Tse, 2015). Numerous studies show the relationship between these two addictions and the psychological and psychiatric consequences they can have on young people (Andreassen et al., 2016; BuizaAguado, Alonso-Canovas, Conde-Mateos, Buiza-Navarrete, \& Gentile, 2018; Cudo, Kopiś, Stróżak, \& Zapała, 2018; Cudo, Torój, Misiuro, \& Griffiths, 2020; King et al., 2013; Kuss \& Griffiths, 2012; Strong et al., 2018; Van-Rooij et al., 2011; Wang et al., 2015).

The connection between social networking and video game addiction is not new (Choi et al., 2015; Derevensky, Hayman, \& Gilbeau, 2019; Kim et al., 2016; McNicol \& Thorsteinsson, 2017; Moreno-Guerrero, Gómez-García, López-Belmonte, \& Rodríguez-Jiménez, 2020). The results the relationship between social network addictions according to factors and video game addictions. However, a connection between the use of toxic substances and video game addiction is not observed, despite high data on alcohol, tobacco, and cannabis use among university youth. This leads us to believe that video game addiction mainly concentrates on a level of addiction inserted into digital technologies, with addiction to social 
networks being the primary determinant. Thus, the research and analysis carried out must consider the common aspects between these two addictions.

This research is based on the hypothesis that the addiction to toxic substances or social networks determined video games' dependence. Socio-demographic variables such as gender, age, or branch of knowledge of the degree we're not determining factors. We can affirm the hypothesis is partially confirmed since, even though addiction to social networks predicts dependence on video games, the same response is not got with addiction to toxic substances. However, gender, a variable not considered a determinant, acts as a predictor, with men presenting a higher risk of being addicted to video games than women.

In this context, the educational world must develop and apply different digital literacy strategies that allow students to face the dangers of the excessive consumption of digital technologies and media (Gómez-Galán, 2003, 2020; Roig-Vila \& Mengual-Andrés, 2014). Among them are video games (Saunders et al., 2017). While moderate use of video games can even have positive educational and/or training effects (Marín-Díaz, Morales-Díaz, \& Reche-Urbano, 2019; Merino \& Castillo, 2016; Moral, 2014), excessive use can lead to dangerous addiction. Health and academic authorities should know the serious individual and social problems that habits can cause and their consequences derived from unhealthy consumption. Hence, they should implement prevention, detection, and treatment programs to tackle them (del Castillo \& Velasco, 2020; Király et al., 2020).

University initiatives for addiction prevention programs, such as those described by Werch, Pappas, and Castellon-Vogel (1996), Zamora (2005) or Milroy et al. (2015), should also specifically contemplate video games today. Precisely, our exploratory study aims to make an approach to the analysis of the problem, present both in Spain and internationally, as it is a global problem.

Such an exceptional circumstance as the COVID-19 pandemic, involving home confinement, has undoubtedly contributed to increasing different addictions (Dong, Yang, Lu, \& Hao, 2020; Gómez-Galán et al., 2020; King \& Potenza, 2019; Király et al., 2020; LázaroPérez, Ángel Martínez-López, \& Gómez-Galán, 2020; Mallet, Dubertret, \& Strat, 2021; Mestre-Bach, Blycker, \& Potenza, 2020). Preventive programs are essential, not only for the present but also for possible similar future scenarios.

The research conducted has some limitations. First, the size of the sample should be noted. It turned out to be more limited than expected, but this was because of the extreme circumstances in which the fieldwork was carried out. At the beginning of June in Spain, the first wave's impact was waning, but all university campuses were still closed, and exams were being conducted using online systems. Because for several weeks, students had been working on their academic activities using virtual platforms. They were highly saturated to carry out the answers through a telematics system such as the one we used.

This meant that in the end, participation was lower than expected, and we discarded those questionnaires that we found had not been answered objectively or had not been given the expected time. At all times, we had the valuable help of university colleagues whom we asked to act as intermediaries to encourage maximum participation. However, a larger sample than that obtained would not have provided us with any more information than that 
finally obtained. From the point of view of an exploratory study, we consider it sufficient to obtain valuable data.

The sample also partly conditioned the statistical analysis related to the dependent variable/gambling addiction's heterogeneous distribution. The use of many predictors can be a strategy that generates problems with the analysis, particularly if the predictors have limited cases in each category, as could have happened due to the small number of participants. It would be interesting to consider the possibility of conceptualizing the dependent variable/gambling addiction as a continuous variable (as opposed to a dichotomous variable), which would perhaps solve the possible statistical and theoretical problems derived from the cross-sectional nature of the study. We will do so in a future comparative research with a larger sample.

We should also understand as a limitation that the focus and development of this research are centered exclusively on an educational and socio-educational level. Although a self-report measure should have been used to estimate the prevalence of a mental problem such as video game addiction, it should in no way be understood as equivalent to a diagnosis in the psychotherapeutic setting. A single self-assessment questionnaire can only indicate that a problem might be present or is likely to be present. For our objectives, which are framed in education, formative evaluation, and the search for preventive measures to address students' problems in higher education, always in the area of socio-educational and not medical-health research, is sufficient. Of course, it should not be understood as research within psychiatry or clinical psychology.

The essential thing was to carry out the process in a rigorous manner and with the highest quality, which was effectively achieved, and all this taking into account the adverse circumstances in which Spain found itself at the time un. We also believe that having obtained this information may be of great interest for future comparative studies. Precisely what we have sought with this study is to get descriptive information on this problem in Spain in the COVID-19 pandemic.

\section{CONCLUSIONS}

The approach to addictions by young university students reflects a problem that can be generalized to all young Spaniards. From a theoretical and empirical perspective, this type of addiction must be analyzed, considered, and treated since it can cause psychological and psychiatric disorders in young people, conditioning their present and future daily activities.

The results, developed during the first wave of the COVID-19 pandemic, should alert the institutions involved by establishing mechanisms for identifying and preventing this addiction. And treatment should be implemented for those subjects who require it, especially if the health crisis context should recur and young university students are once again confined. In this sense, it is essential to implement health prevention programs that include the consequences of addiction to digital technologies, relating video game addiction to social networks. In this way, the fight against this addiction, which is so silent about others, such as toxic substances, is decisive. 
As Carbonell (2020) points out, video game addiction is a relevant challenge for professionals because of the need to respond effectively to the symptoms and the disorder itself. Still, it is also essential to know the characteristics of the video games and the players who use them, the social context, and the comorbidity. All this will help better to understand the disorder, its diagnosis, and treatment. Finally, and especially when the world is free of this pandemic that is plaguing it and for those people most prone to this addiction, a change of habits towards others related to physical exercise and recovery of physical, social relationships that avoid permanent contact with the Internet and video games, in particular, should be encouraged.

\section{REFERENCES}

Aarseth, E., Bean, A. M., Boonen, H., Carras, M. C., Coulson, M., Das, D., ... Rooij, A. J. V. (2017). Scholars' open debate paper on the World Health Organization ICD-11 Gaming Disorder proposal. Journal of Behavioral Addictions, 6(3), 267-270. https://doi.org/10.1556/ 2006.5.2016.088

American Psychiatric Association. (2013). Diagnostic and Statistical Manual of Mental Disorders $\left(D S M-5^{\circ}\right)(5$, Ed.). American Psychiatric Association.

Andreassen, C. S., Billieux, J., Griffiths, M. D., Kuss, D. J., Demetrovics, Z., Mazzoni, E., \& Pallesen, S. (2016). The relationship between addictive use of social media and video games and symptoms of psychiatric disorders: A large-scale cross-sectional study. Psychology of Addictive Behaviors, 30(2), 252-262. https://doi.org/10.1037/adb0000160

Ariza, A. C., Monzonís, N. C., Magaña, E. C., \& Méndez, V. G. (2021). Jóvenes y uso problemático de las tecnologías durante la pandemia: una preocupación familiar. Hachetetepé. Revista científica de Educación y Comunicación, 22(22), 1-12. https://doi.org/10.25267/hachetetepe.2021.i22 .1204

Balluerka, M. N., Benito, J., Hidalgo, M. D., Gorostiaga, M. A., Espada, J. P., Padilla, J. L., \& Santed, M. A. (2020). Las Consecuencias Psicológicas de la COVID-19 y el Confinamiento. Informe de investigación. Servicios de Publicaciones de la Universidad del País Vasco.

Becerra, F. (2011). Relación entre el hábito de consumo de videojuegos y el rendimiento académico, diferencias de género y edad en tercer ciclo de educación primaria. INFAD Revista de Psicología, 2(1), 347-356.

Beltrán, V. J., Devís, J., \& Peiró, C. (2012). Actividad física y sedentarismo en adolescentes de la Comunidad Valenciana. Revista Internacional de Medicina y Ciencias de la Actividad Física y del Deporte, 12(45), 123-137.

Berlanga, V., \& Vilà, R. (2014). Cómo obtener un modelo de regresión logística binaria con SPSS. Revista d'Innovació i Recerca en Educació, 7, 105-118.

Brunborg, G. S., Mentzoni, R. A., \& Frøyland, L. R. (2014). Is video gaming, or video game addiction, associated with depression, academic achievement, heavy episodic drinking, or conduct problems? Journal of Behavioral Addictions, 3(1), 27-32. https://doi.org/10.1556/jba.3.2014.002

Buiza-Aguado, C., Alonso-Canovas, A., Conde-Mateos, C., Buiza-Navarrete, J. J., \& Gentile, D. (2018). Problematic Video Gaming in a Young Spanish Population: Association with Psychosocial Health. Cyberpsychology, Behavior, and Social Networking, 21(6), 388-394. https:// doi.org/10.1089/cyber.2017.0599

Buiza-Aguado, C., García-Calero, A., Alonso-Cánovas, A., Ortiz-Soto, P., Guerrero-Díaz, M., González-Molinier, M., \& Hernández-Medrano, I. (2017). Los videojuegos: una afición 
con implicaciones neuropsiquiátricas. Psicología Educativa, 23(2), 129-136. https://doi.org/ 10.1016/j.pse.2017.05.001

Buono, F. D., Paul, E., Sprong, M. E., Smith, E. C., Garakani, A., \& Griffiths, M. D. (2020). Gaming and Gaming Disorder: A Mediation Model Gender, Salience, Age of Gaming Onset, and Time Spent Gaming. Cyberpsychology, Behavior, and Social Networking, 23(9), 647-651. https:// doi.org/10.1089/cyber.2019.0445

Cabrero, R. S., \& Óscar Costa Román. (2018). Psychopedagogical Predecessors of Connectivism as a New Paradigm of Learning. International Journal of Educational Excellence, 4(2), 29-45. https://doi.org/10.18562/ijee.037

Cangas, Navarro, Aguilar-Parra, Trigueros, Gallego, Zárate, \& Gregg. (2019). Analysis of the Usefulness of a Serious Game to Raise Awareness about Mental Health Problems in a Sample of High School and University Students: Relationship with Familiarity and Time Spent Playing Video Games. Journal of Clinical Medicine, 8(10), 1504-1504. https://dx.doi.org/10.3390/ jcm810150410.3390/jcm8101504

Carbonell, X. (2020). El diagnóstico de adicción a videojuegos en el DSM-5 y la CIE-11: Retos y oportunidades para clínicos. Papeles del Psicólogo, 41(3), 1-8.

Carbonell, X., Chamarro, A., Oberst, U., Rodrigo, B., \& Prades, M. (2018). Problematic Use of the Internet and Smartphones in University Students: 2006-2017. International Journal of Environmental Research and Public Health, 15(3), 475-475. https://doi.org/10.3390/ ijerph15030475

Carnagey, N. L., Anderson, C. A., \& Bushman, B. J. (2007). The effect of video game violence on physiological desensitization to real-life violence. Journal of Experimental Social Psychology, 43(3), 489-496. https://doi.org/10.1016/j.jesp.2006.05.003

Carrillo, J. A. (2015). La dimensión social de los videojuegos online: De las comunidades de jugadores a los e-sports. Comunicación: Revista Científica en el Ámbito de la Comunicación Aplicada, 5(1), 39-51.

Chamarro, A., Carbonell, X., Manresa, J. M., Munoz-Miralles, R., Ortega-Gonzalez, R., LopezMorron, M. R., ... Toran-Monserrat, P. (2014). El Cuestionario de Experiencias Relacionadas con los Videojuegos (CERV): Un instrumento para detectar el uso problemático de videojuegos en adolescentes españoles. Adicciones, 26(4), 303-303. https://doi.org/10.20882/ adicciones. 31

Choi, S. W., Kim, D. J., Choi, J. S., Ahn, H., Choi, E. J., \& Song, W. Y. (2015). Comparison of risk and protective factors associated with smartphone addiction and Internet addiction. Journal of Behavioral Addictions, 4(4), 308-314. https://doi.org/10.1556/2006.4.2015.043

Cimino, S., Simonelli, A., Parolin, M., Ballarotto, G., Carbone, P., \& Cerniglia, L. (2018). A Theoretical and Empirical Linkage between Road Accidents and Binge Eating Behaviors in Adolescence. International Journal of Environmental Research and Public Health, 15(2), 355-355. https://doi.org/10.3390/ijerph15020355

Coknaz, D., Mirzeoglu, A. D., Atasoy, H. I., Alkoy, S., Coknaz, H., \& Goral, K. (2019). A digital movement in the world of inactive children: favourable outcomes of playing active video games in a pilot randomized trial. European Journal of Pediatrics, 178(10), 1567-1576. https://doi.org/10.1007/s00431-019-03457-x

Connolly, T. M., Boyle, E. A., MacArthur, E., Hainey, T., \& Boyle, J. M. (2012). A systematic literature review of empirical evidence on computer games and serious games. Computers \& Education, 59(2), 661-686. https://doi.org/10.1016/j.compedu.2012.03.004

Cuberos, R. C., Ortega, F. Z., Martínez, A. M., Sánchez, M. C., Garcés, T. E., \& Martínez, C. P. (2017). Relación entre factores académicos y consumo de videojuegos en universitarios. Un modelo de regresión. Pixel-Bit, Revista de Medios y Educación, 50(50), 109-121. https:// 
doi.org/10.12795/pixelbit.2017.i50.07

Cudo, A., Kopiś, N., Stróżak, P., \& Zapała, D. (2018). Problematic Video Gaming and Problematic Internet Use Among Polish Young Adults. Cyberpsychology, Behavior, and Social Networking, 21(8), 523-529. https://doi.org/10.1089/cyber.2018.0014

Cudo, A., Torój, M., Misiuro, T., \& Griffiths, M. D. (2020). Problematic Facebook Use and Problematic Video Gaming Among Female and Male Gamers. Cyberpsychology, Behavior, and Social Networking, 23(2), 126-133. https://doi.org/10.1089/cyber.2019.0252

del Castillo, R. P., \& Velasco, M. F. P. (2020). Salud mental infanto-juvenil y pandemia de Covid-19 en España: cuestiones y retos. Revista de Psiquiatría Infanto-Juvenil, 37(2), 30-44. https:// doi.org/10.31766/revpsij.v37n2a4

Derevensky, J. L., Hayman, V., \& Gilbeau, L. (2019). Behavioral addictions: excessive gambling, gaming, Internet, and smartphone use among children and adolescents. Pediatric Clinics, 66(5), 1163-1182. https://doi.org/10.1016/j.pcl.2019.08.008

Dong, H., Yang, F., Lu, X., \& Hao, W. (2020). Internet Addiction and Related Psychological Factors Among Children and Adolescents in China During the Coronavirus Disease 2019 (COVID19) Epidemic. Frontiers in Psychiatry, 11, 751-751. https://doi.org/10.3389/fpsyt.2020.00751

Escurra, M., \& Salas, E. (2014). Construcción y validación del cuestionario de adicción a redes sociales (ARS). Liberabit, 20(1), 73-91.

Fam, J. Y. (2018). Prevalence of internet gaming disorder in adolescents: A meta-analysis across three decades. Scandinavian Journal of Psychology, 59(5), 524-531. https://doi.org/10.1111/ sjop. 12459

Friedman, E. (2020). Internet Addiction: A Critical Psychology of Users. Routledge.

García-Bellido, R., González Such, J., \& Jornet, M. (2010). SPSS Análisis de Fiabilidad: Alfa de Cronbach. Universitat de València.

Gómez-Galán, J. (2003). Educar en Nuevas Tecnologías y Medios de Comunicación. FEP.

Gómez-Galán, J. (2020). Media Education in the ICT Era: Theoretical Structure for Innovative Teaching Styles. Information, 11(5), 276-276. https://doi.org/10.3390/info11050276

Gómez-Galán, J., Ángel Martínez-López, J., Lázaro-Pérez, C., \& García-Cabrero, J. C. (2021). Open Innovation during Web Surfing: Topics of Interest and Rejection by Latin American College Students. Journal of Open Innovation: Technology, Market, and Complexity, 7(1), 17-17. https://doi.org/10.3390/joitmc7010017

Gómez-Galán, J., Ángel Martínez-López, J., Lázaro-Pérez, C., \& Sánchez-Serrano, J. L. S. (2020). Social Networks Consumption and Addiction in College Students during the COVID-19 Pandemic: Educational Approach to Responsible Use. Sustainability, 12(18), 7737-7737. https://doi.org/10.3390/su12187737

González-Zamar, M.-D., Abad-Segura, E., López-Meneses, E., \& Gómez-Galán, J. (2020). Managing ICT for Sustainable Education: Research Analysis in the Context of Higher Education. Sustainability, 12(19), 8254-8254. https://doi.org/10.3390/su12198254

Goudriaan, A. E., Oosterlaan, J., de Beurs, E., \& den Brink, W. V. (2004). Pathological gambling: a comprehensive review of biobehavioral findings. Neuroscience \& Biobehavioral Reviews, 28(2), 123-141. https://doi.org/10.1016/j.neubiorev.2004.03.001

Griffiths, M. D., \& Pontes, H. M. (2014). Internet addiction disorder and internet gaming disorder are not the same. Journal of Addiction Research \& Therapy, 5(4). https://doi.org/10.4172/ 2155-6105.1000e124

Hsieh, K. Y., Hsiao, R. C., Yang, Y. H., Liu, T. L., \& Yen, C. F. (2018). Predictive effects of sex, age, depression, and problematic behaviors on the incidence and remission of internet addiction in college students: a prospective study. International Journal of Environmental Research and Public Health, 15(12), 2861-2861. https://doi.org/10.3390/ijerph15122861 
Irles, D. L., Gomis, R. M., Campos, J. C. M., \& González, S. T. (2018). Validación española de la Escala de Adicción a Videojuegos para Adolescentes (GASA). Atención Primaria, 50, 350-358. https://doi.org/10.1016/j.aprim.2017.03.015

Irles, D. L., Perona, V. C., \& Baños, Y. S. (2015). Relaciones entre hábitos de uso de videojuegos, control parental y rendimiento escolar. European Journal of Investigation in Health, Psychology and Education, 3(3), 237-237. https://doi.org/10.30552/ejihpe.v3i3.58

Kim, Y., Jeong, J. E., Cho, H., Jung, D. J., Kwak, M., \& Rho, M. J. (2016). Personality factors predicting smartphone addiction predisposition: Behavioral inhibition and activation systems, impulsivity, and self-control. PloS One, 11(8). https://doi.org/10.1371/journal.pone.0159788

King, D. L., Delfabbro, P. H., Zwaans, T., \& Kaptsis, D. (2013). Clinical features and axis I comorbidity of Australian adolescent pathological Internet and video game users. Australian \& New Zealand Journal of Psychiatry, 47(11), 1058-1067. https://doi.org/10.1177/ 0004867413491159

King, D. L., \& Potenza, M. N. (2019). Not Playing Around: Gaming Disorder in the International Classification of Diseases (ICD-11). Journal of Adolescent Health, 64(1), 5-7. https://doi.org/ 10.1016/j.jadohealth.2018.10.010

Király, O., \& Demetrovics, Z. (2017). Inclusion of Gaming Disorder in ICD has more advantages than disadvantages: Commentary on: Scholars' open debate paper on the World Health Organization ICD-11 Gaming Disorder proposal (Aarseth et al.). Journal of Behavioral Addictions, 6(3), 280-284. https://doi.org/10.1556/2006.6.2017.046

Király, O., Potenza, M. N., Stein, D. J., King, D. L., Hodgins, D. C., \& Saunders, J. B. (2020). Preventing problematic internet use during the COVID-19 pandemic: Consensus guidance. Comprehensive Psychiatry, 100, 152180-152180. https://doi.org/10.1016/j.comppsych.2020.152180

Kuss, D. J., \& Griffiths, M. D. (2012). Internet Gaming Addiction: A Systematic Review of Empirical Research. International Journal of Mental Health and Addiction, 10(2), 278-296. https://doi .org/10.1007/s11469-011-9318-5

Kuss, D. J., Louws, J., \& Wiers, R. W. (2012). Online Gaming Addiction? Motives Predict Addictive Play Behavior in Massively Multiplayer Online Role-Playing Games. Cyberpsychology, Behavior, and Social Networking, 15(9), 480-485. https://doi.org/10.1089/cyber.2012.0034

Lázaro-Pérez, C., Ángel Martínez-López, J., \& Gómez-Galán, J. (2020). Addictions in Spanish College Students in Confinement Times: Preventive and Social Perspective. Social Sciences, 9(11), 195-195. https://doi.org/10.3390/socsci9110195

Lemmens, J. S., Valkenburg, P. M., \& Peter, J. (2009). Development and Validation of a Game Addiction Scale for Adolescents. Media Psychology, 12(1), 77-95. https://doi.org/10.1080/ 15213260802669458

Llorca, M. A., Bueno, G. M., Villar-Fernández, C., \& Diez, M. A. (2010). Frecuencia en el uso de videojuegos y rendimiento académico. Actas del II Congreso Internacional Comunicación 3.0. Universidad de Salamanca. Retrieved from http://campus.usal.es/ comunicacion3punto0/ comunicaciones/022.pdf

Mallet, J., Dubertret, C., \& Strat, Y. L. (2021). Addictions in the COVID-19 era: Current evidence, future perspectives a comprehensive review. Progress in Neuro-Psychopharmacology and Biological Psychiatry, 106(2), 110070-110070. https://doi.org/10.1016/j.pnpbp.2020.110070

Marín-Díaz, V., Morales-Díaz, M., \& Reche-Urbano, E. (2019). Educational Possibilities of Video Games in the Primary Education Stage According to Teachers in Training. A Case Study. Journal of New Approaches in Educational Research, 8(1), 42-49. https://doi.org/10.7821/ naer.2019.1.330

Marston, H. R., \& Kowert, R. (2020). What role can videogames play in the COVID-19 pandemic. Emerald Open Research, 2, 34-34. 
McNicol, M. L., \& Thorsteinsson, E. B. (2017). Internet Addiction, Psychological Distress, and Coping Responses Among Adolescents and Adults. Cyberpsychology, Behavior, and Social Networking, 20(5), 296-304. https://doi.org/10.1089/cyber.2016.0669

Mentzoni, R. A., Brunborg, G. S., Molde, H., Myrseth, H., Skouverøe, K. J. M., Hetland, J., \& Pallesen, S. (2011). Problematic Video Game Use: Estimated Prevalence and Associations with Mental and Physical Health. Cyberpsychology, Behavior, and Social Networking, 14(10), 591-596. https://doi.org/10.1089/cyber.2010.0260

Merino, C., \& Castillo, H. (2016). The benefits of active video games for educational and physical activity approaches: A systematic review. Journal of New Approaches in Educational Research, 5(2), 115-122. https://doi.org/10.7821/naer.2016.7.164

Mestre-Bach, G., Blycker, G. R., \& Potenza, M. N. (2020). Pornography use in the setting of the COVID-19 pandemic. Journal of Behavioral Addictions, 9(2), 181-183. https://doi.org/10 $.1556 / 2006.2020 .00015$

Milroy, J. J., Orsini, M. M., Wyrick, D. L., Fearnow-Kenney, M., Wagoner, K. G., \& Caldwell, R. (2015). Implementing an Alcohol and Other Drug Use Prevention Program Using UniversityHigh School Partnerships: Challenges and Lessons Learned. American Journal of Health Education, 46(5), 310-313. https://doi.org/10.1080/19325037.2015.1055015

Mishra, J., Anguera, J. A., \& Gazzaley, A. (2016). Video Games for Neuro-Cognitive Optimization. Neuron, 90(2), 214-218. https://doi.org/10.1016/j.neuron.2016.04.010

Moral, M. E. D. (2014). Videogames: Opportunities for learning. Journal of New Approaches in Educational Research, 3(1), 1-3. https://doi.org/10.7821/naer.3.1.1

Moreno-Guerrero, A.-J., Gómez-García, G., López-Belmonte, J., \& Rodríguez-Jiménez, C. (2020). Internet Addiction in the Web of Science Database: A Review of the Literature with Scientific Mapping. International Journal of Environmental Research and Public Health, 17(8), 27532753. https://doi.org/10.3390/ijerph17082753

Ni, X., Yan, H., Chen, S., \& Liu, Z. (2009). Factors influencing internet addiction in a sample of freshmen university students in China. Cyberpsychology \& Behavior, 12(3), 327-330.

Orte, C., \& Nevot-Caldentey, L. (2020). Manual de Recursos para Familias en Confinamiento. Octaedro.

Parra, M. E., Segura, A., Morales, M. B., \& López-Meneses, E. L. (2020). Relación de los factores asociados en el desarrollo de experiencias gamificadas. Campus Virtuales, 9(1), 113-123.

Pasquale, C. D., Chiappedi, M., Sciacca, F., Martinelli, V., \& Hichy, Z. (2021). Online Videogames Use and Anxiety in Children during the COVID-19 Pandemic. Children, 8(3), 205-205. https:// doi.org/10.3390/children8030205

Paulus, F. W., Ohmann, S., von Gontard, A., \& Popow, C. (2018). Internet gaming disorder in children and adolescents: a systematic review. Developmental Medicine \& Child Neurology, 60(7), 645-659. https://doi.org/10.1111/dmcn.13754

Phan, O., Prieur, C., Bonnaire, C., \& Obradovic, I. (2020). Internet Gaming Disorder: Exploring Its Impact on Satisfaction in Life in PELLEAS Adolescent Sample. International Journal of Environmental Research and Public Health, 17(1), 3-3. https://doi.org/10.3390/ijerph17010003

Prot, S., McDonald, K. A., Anderson, C. A., \& Gentile, D. A. (2012). Video Games: Good, bad, or other? Pediatric Clinics of North America, 59(3), 647-658. https://doi.org/10.1016/j.pcl.2012 .03 .016

Quaglieri, A., Mari, E., Boccia, M., Piccardi, L., Guariglia, C., \& Giannini, A. M. (2020). Brain Network Underlying Executive Functions in Gambling and Alcohol Use Disorders: An Activation Likelihood Estimation Meta-Analysis of fMRI Studies. Brain Sciences, 10(6), 353-353. https://doi.org/10.3390/brainsci10060353

Roig-Vila, R., \& Mengual-Andrés, S. (2014). New Literacy for Reading Using ICT. ECPS - Educa- 
tional, Cultural and Psychological Studies, 10(10), 431-442. Retrieved from https://dx.doi.org/ 10.7358/ecps-2014-010-roig 10.7358/ecps-2014-010-roig

Roig-Vila, R., \& Moreno-Isac, V. (2020). El pensamiento computacional en Educación. Análisis bibliométrico y temático. Revista De Educación a Distancia (RED), 20(63), 20-20. https:// doi.org/10.6018/red.402621

Rosa, J. D. C., Bucheli, M. G. V., Galán, J. G., \& Meneses, E. L. (2019). Integrating the Digital Paradigm in Higher Education: ICT Training and Skills of University Students in a European Context. International Journal of Educational Excellence, 5(2), 47-64. https://doi.org/ 10.18562/ijee. 048

Ross, M. W., Månsson, S.-A., \& Daneback, K. (2012). Prevalence, Severity, and Correlates of Problematic Sexual Internet Use in Swedish Men and Women. Archives of Sexual Behavior, 41(2), 459-466. https://doi.org/10.1007/s10508-011-9762-0

Saunders, J. B., Hao, W., Long, J., King, D. L., Mann, K., \& Fauth-Bühler, M. (2017). Gaming disorder: Its delineation as an important condition for diagnosis, management, and prevention. Journal of Behavioral Addictions, 6(3), 271-279. https://doi.org/10.1556/2006.6.2017.039

Strong, C., Lee, C. T., Chao, L. H., Lin, C. Y., \& Tsai, M. C. (2018). Adolescent Internet use, social integration, and depressive symptoms: Analysis from a longitudinal cohort survey. Journal of Developmental \& Behavioral Pediatrics, 39(4), 318-324. https://doi.org/10.1097/ dbp.0000000000000553

Tejeiro, R. A., \& Bersabé, R. M. (2002). Measuring problem video game playing in adolescents. Addiction, 97(12), 1601-1606. https://doi.org/10.1046/j.1360-0443.2002.00218.x

Torre-Luque, A., \& Aguayo, L. V. (2013). Factores moduladores de la respuesta agresiva en la exposición a videojuegos violentos. Anales de Psicología, 29(2), 311-318. https://doi.org/10.6018/ analesps.29.2.132071

Van-Rooij, A. J., Schoenmakers, T. M., Vermulst, A. A., Den Eijnden, V., \& De Mheen, V. (2011). Online video game addiction: identification of addicted adolescent gamers. Addiction, 106(1), 205-212. https://doi.org/10.1111/j.1360-0443.2010.03104.x

Wang, C. W., Ho, R. T., Chan, C. L., \& Tse, S. (2015). Exploring personality characteristics of Chinese adolescents with internet-related addictive behaviors: Trait differences for gaming addiction and social networking addiction. Addictive Behaviors, 42, 32-35.

Werch, C. E., Pappas, D. M., \& Castellon-Vogel, E. A. (1996). Drug Use Prevention Efforts at Colleges and Universities in the United States. Substance Use \& Misuse, 31(1), 65-80. https://doi.org/ $10.3109 / 10826089609045798$

WHO ASSIST Working Group. (2002). The alcohol, smoking and substance involvement screening test (ASSIST): development, reliability and feasibility. Addiction, 97(9), 1183-1194. https:// doi.org/10.1046/j.1360-0443.2002.00185.x

Zamora, Z. (2005). Teaching activities in the program for health promotion and addiction prevention in 2003-2004. Revista Latino-Americana de Enfermagem, 13(2), 1201-1206. https:// doi.org/10.1590/s0104-11692005000800015 